\title{
Effects of forest fragmentation on birds of the cerrado region, Brazil
}

\author{
MIGUEL Â. MARINI
}

\begin{abstract}
Summary
Bird surveys were conducted through observations and mist-netting in six forest fragments in the cerrado region of central Brazil, to evaluate the effects of fragmentation on bird species richness and community composition. Smaller forest fragments had fewer species than larger fragments. The proportion of species in most foraging guilds did not change with forest size, except for that of granivores, which decreased as fragment size increased. The proportion of forest-dependent species increased significantly with increasing fragment size while that of semi-dependent species significantly decreased. Forest-dependent endemic birds, however, were not area sensitive, but appeared to be partially dependent on the flooded forests of the region. Conservation policies for the region should conserve both large and small forest fragments urgently, and flooded forests especially.
\end{abstract}

\section{Introduction}

The cerrado region, which covers $25 \%$ of Brazil, is a biome unique to the Neotropics. Its original vegetation consists of a mixture of grasslands, "cerrado" sensu stricto vegetation (a scrub-like savanna), dry-semideciduous forests, and gallery forests along watercourses. However, natural habitats of the cerrado have been rapidly converted into plantations, pasturelands and other habitats generating a mosaic of habitat fragments of variable size and degree of isolation. Today, only $6.6 \%$ of the region is in natural reserves, with the remaining area covered either by transformed (e.g. crops, urban areas) or managed (e.g. native pasture, timber exploitation) areas (Dias 1990). Willis and Oniki (1993) considered the Brazilian cerrado to be the most rapidly disappearing habitat in the world.

Habitat area is the best predictor of species number (richness) for many groups of organisms (Shafer 1990), with richness increasing with habitat patch size (Abbott 1980, Andrén 1994, Hagan et al. 1996). Few studies of bird communities in fragmented landscapes have been carried out in the Neotropical region (Turner 1996). Those that have are mostly from the Minimum Critical Size of Ecosystems Study (now Biological Dynamics of Forest Fragments Project) in Brazilian Amazon (e.g. Bierregaard and Lovejoy 1986, 1989, Bierregaard et al. 1992). The few other existing examples of species-area relationships in Neotropical forest fragments include Willis's (1979) study of three Atlantic Forest fragments, Leck's (1979) study of Ecuadorian forests, Kattan and Alvarez-López's (1996) study of Colombian Andes birds, and Christiansen and Pitter's (1997) and Anjos 
and Boçon's (1999) study of 3 and 12 forest fragments in south-east Brazil, respectively.

Considering the variety of habitats in the Neotropical region, and the existence of exceptions to the species-area relationship (review in Andrén 1994), patterns proposed for different biomes or regions of the world, especially temperate zones, should be evaluated for all Neotropical habitats before being widely accepted. For example, contrary to what has been shown in several regions of the world, Melo and Marini (1997) and Leite and Marini (1999) showed that predation rates on artificial nests do not increase with decreasing fragment size in south-eastern Brazilian forests.

The aim of this study was to compare bird communities between forest fragments of different sizes, by examining the relationship between forest fragment size and (1) bird species richness, (2) levels of bird forest dependence (dependent, semi-dependent and independent), and (3) foraging guilds.

\section{Study area}

The study was conducted between February 1994 and April 1996 in six forest fragments in the Triângulo Mineiro region (elevation $\sim 800 \mathrm{~m}$ a.s.l.), near Uberlândia, Minas Gerais state, Brazil (Figure 1). Uberlândia has warm rainy summers (October-March) and cool dry winters (April-September) (Rosa et al. 1991), with a mean annual temperature of $22^{\circ} \mathrm{C}$ and mean annual rainfall of $1,550 \mathrm{~mm}$.

Forest fragments ranged in size from $7 \cdot 5$ to 230 ha (Table 1), were surrounded in large part by pasture, and were separated from each other by a few to several hundred meters. Seventy-five percent of Uberlândia county has already been converted into pastures and crops. The dominant vegetation of the fragments was tropical dry forest. Fragments differed in the presence or absence of flooded forests, and with respect to the level of disturbance of the forest. Canopy height was usually between 15 and $20 \mathrm{~m}$ with some emergent trees up to $25 \mathrm{~m}$. Details of the vegetation of the region can be found in Schiavini and Araújo (1989), Araújo and Haridasan (1997), Araújo et al. (1997), and Rodrigues and Araújo (1997).

\section{Methods}

Bird surveys were conducted mostly during the dry season (April-September), and never during periods of rain or strong wind. Observations occurred mainly in the mornings (o6hoo-11 hoo) by walking slowly ( $\sim \mathrm{km} /$ hour), mostly on trails, along watercourses, and forest borders. Only birds heard and/or observed in the fragment or perched on a plant that was rooted in the fragment were recorded. Birds observed flying over the fragment were not included. Unidentified bird vocalizations were tape-recorded and identified subsequently.

Mist-netting was conducted to detect cryptic and shy species difficult to record during walks. Mist-netting was conducted mostly on permanent 500-m transects with 10-20 mist-nets (mesh size $35 \mathrm{~mm}$ ), one at every $50 \mathrm{~m}$. Nets were open mostly between 06 hoo and 14 hoo, with total effort ranging from 316 to 824 mist- 


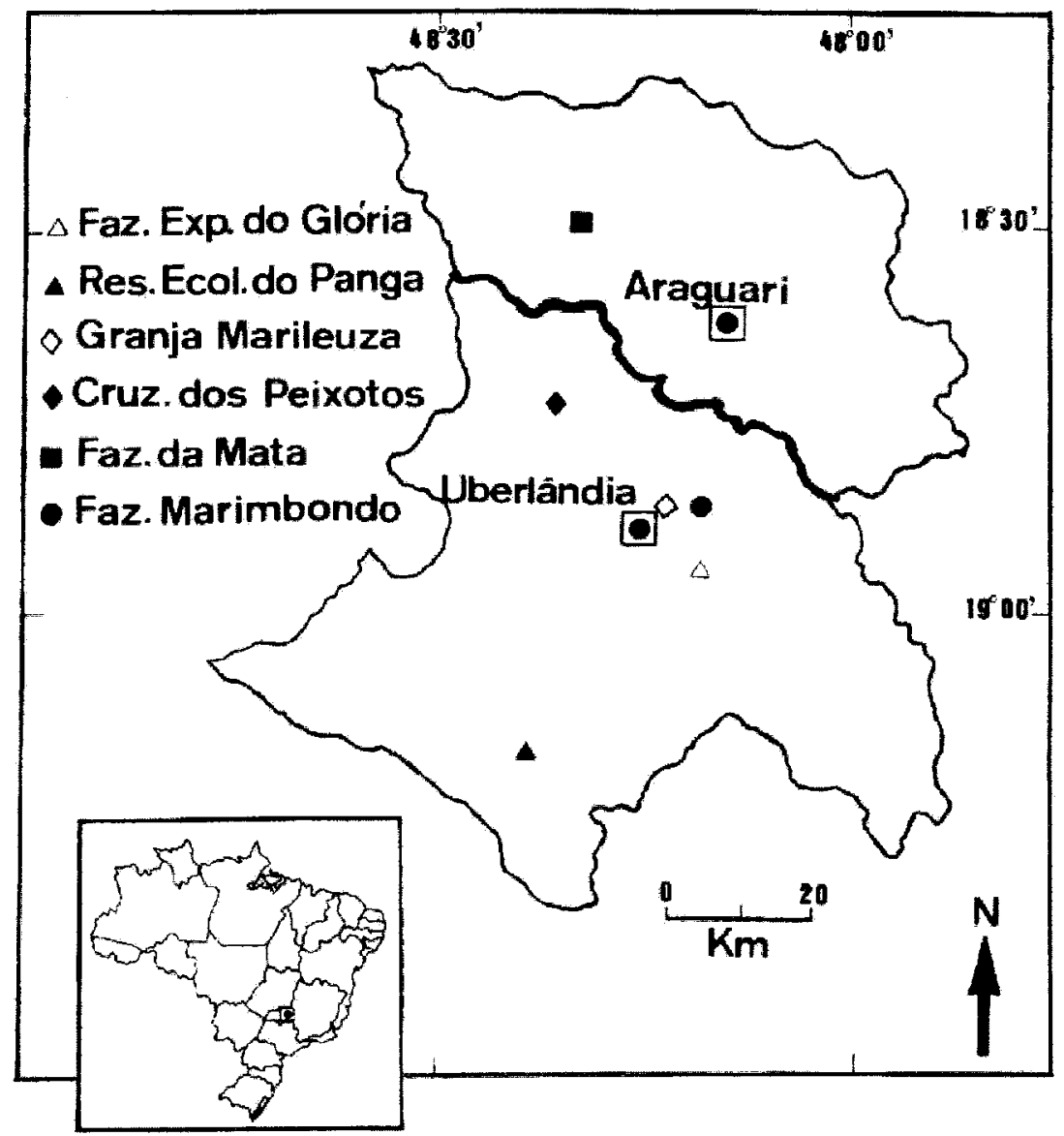

Figure 1. Map of the study area showing the five study sites at the Triângulo Mineiro region, Minas Gerais state, Brazil. The two smaller forest fragments ( 7.5 and 9 ha) were located at Granja Marileuza.

Table 1. Area, geographical coordinates, and total observation and mist-netting effort at six forest fragments in the Triângulo Mineiro region, Minas Gerais state, Brazil

\begin{tabular}{lrllcc}
\hline Fragment & $\begin{array}{l}\text { Area } \\
\text { (ha) }\end{array}$ & $\begin{array}{l}\text { Forest type } \\
\text { (vegetation) }\end{array}$ & $\begin{array}{l}\text { Geographical } \\
\text { coordinates }\end{array}$ & $\begin{array}{l}\text { Observation } \\
\text { hours }\end{array}$ & $\begin{array}{l}\text { Mist-net } \\
\text { hours }\end{array}$ \\
\hline Fazenda da Mata & 230 & Dry-humid & $48^{\circ} \mathrm{O3}^{\prime} \mathrm{W} ; 18^{\circ} 30^{\prime} \mathrm{S}$ & 51 & 676 \\
Cruzeiro dos Peixotos & 155 & Dry & $48^{\circ} 21^{\prime} \mathrm{W} ; 18^{\circ} 46^{\prime} \mathrm{S}$ & 45 & 611 \\
Fazenda Experimental do Glória & 54 & Dry-humid & $48^{\circ} 13^{\prime} \mathrm{W} ; 18^{\circ} 52^{\prime} \mathrm{S}$ & 40 & 824 \\
Reserva Ecológica do Panga & 24 & Dry-humid & $48^{\circ} 21^{\prime} \mathrm{W} ; 19^{\circ} 11^{\prime} \mathrm{S}$ & 32 & 549 \\
Granja Marileuza (dry) & 9 & Dry & $48^{\circ} 15^{\prime} \mathrm{W} ; 18^{\circ} 52^{\prime} \mathrm{S}$ & 24 & 339 \\
Granja Marileuza (flooded) & $7 \cdot 5$ & Humid & $48^{\circ} 15^{\prime} \mathrm{W} ; 18^{\circ} 52^{\prime} \mathrm{S}$ & 24 & 316 \\
Total & 479.5 & & 216 & 3,315 \\
\hline
\end{tabular}


net hours (Table 1). One mist-net hour consisted of one 12-m net open for one hour. Captured birds received a numbered metal ring.

One of the strongest criticisms of species-area studies is that organisms are considered independently of their association with the habitat under consideration. Therefore, species were categorized by (a) their forest dependence (dependent, semi-dependent and independent), according to Silva (1995); (b) their endemism or quasi-endemism to the cerrado region or to Brazil, according to Sick (1997); and (c) their diet, following Willis (1979), Motta-Júnior (1990), Sick (1997) and personal observations.

Pearson's $(r)$ correlation coefficients were calculated between dependent variables (log number of species, log number of genera) and forest fragment area (log ha). Analyses of changes in species composition by foraging guild and by habitat dependence were made using the percentage of species in each category, with total sampling effort as in Table 1. Pearson's $(r)$ correlation coefficients between percentage of species in a guild category and fragment area were calculated after angular transformation (arcsine square root) of the percentage of species (Ott 1988). The same transformation was used for the percentage of species categorized by habitat dependence.

\section{Results}

Excluding aquatic (Threskiornithidae, Ardeidae and Alcedinidae), aerial (Falconiformes) and nocturnal (Tytonidae, Strigidae and Caprimulgidae) species, 145 species in 115 genera in all forest fragments were detected (Appendix 1), including 12 species of special conservation importance. Seven of these were forest-dependent species endemic or quasi-endemic to the cerrado region (Bare-faced Curassow Crax fasciolata, Large-billed Antwren Herpsilochmus longirostris, Sharp-tailed Streamcreeper Lochmias nematura, Russet-mantled Foliagegleaner Phylidor dimidiatus, Chestnut-capped Foliage-Gleaner Automolus rectirostris, Helmeted Manakin Antilophia galeata and White-striped Warbler Basileuterus leucophrys) and five were species endemic or quasi-endemic to open areas of the cerrado region but also use forest fragments (Small-billed Tinamou Crypturellus parvirostris, Toco Toucan Ramphastos toco, Campo Flicker Colaptes campestris, Narrow-billed Woodcreeper Lepidocolaptes angustirostris and Curlcrested Jay Cyanocorax cristatellus).

Species richness increased with forest fragment size when considering both total sampling effort ( $r=0.951, d f=5, P=0.004$ ) and initial sampling effort (first 24 hs of observation and first 320 hours of mist netting) for each fragment $(r=$ o.829, $d f=5, P=0.042$ ) (Figure 2, Appendix 1).

The proportion of forest dependent species increased significantly $(r=0.956$, $d f=5, P=0.003$ ) with increasing fragment area (Figure 3 ), while that of semidependent species decreased significantly $(r=-0.946, d f=5, P=0.004)$, and the proportion of forest independent species did not change $(r=-0.604, d f=5, P=$ 0.204) (Figure 3).

Endemic species did not appear to be area sensitive. The occurrence of forestdependent endemic or quasi-endemic cerrado species did not follow the same pattern for all species, and was unrelated to forest fragment size for both sampling efforts (Table 2). With the exception of two forest endemics (Large-billed 


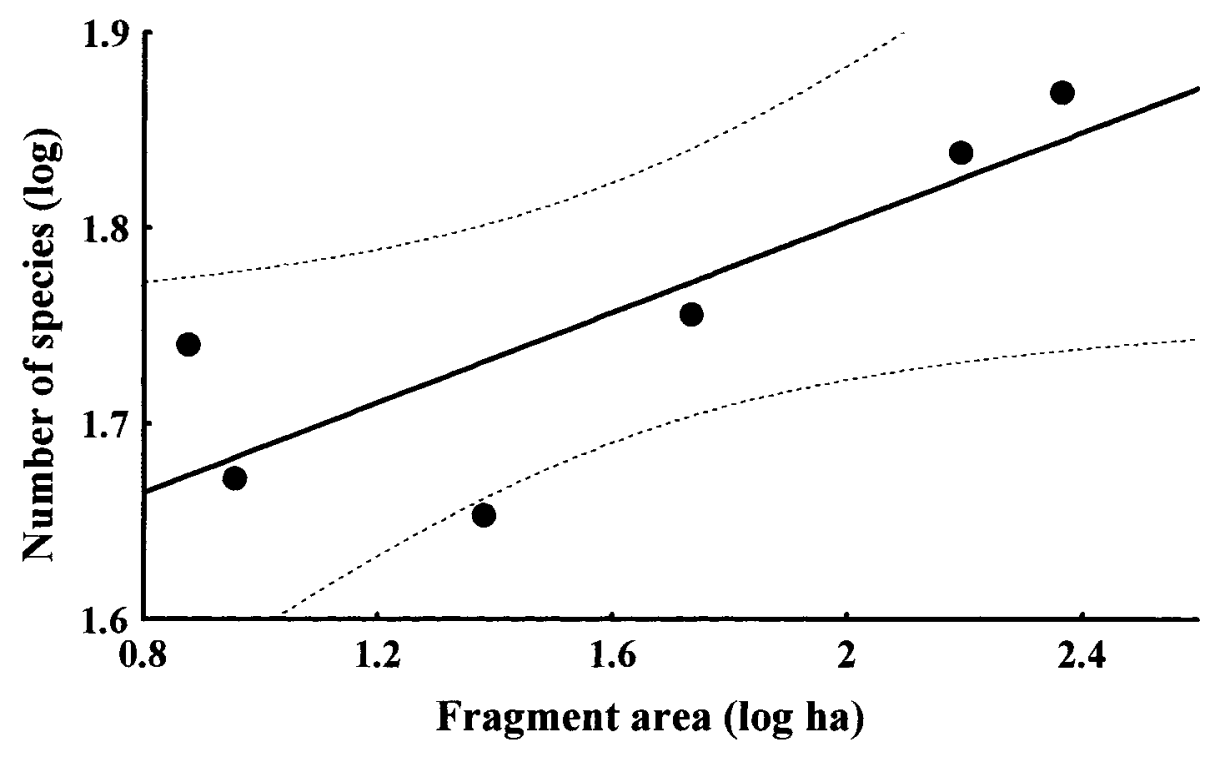

Figure 2. Correlation between log number of species and fragment size (log ha) for the six forest fragments at the Triângulo Mineiro region, Brazil. Sampling effort of 24 observation hours and of 32 mist-netting hours.

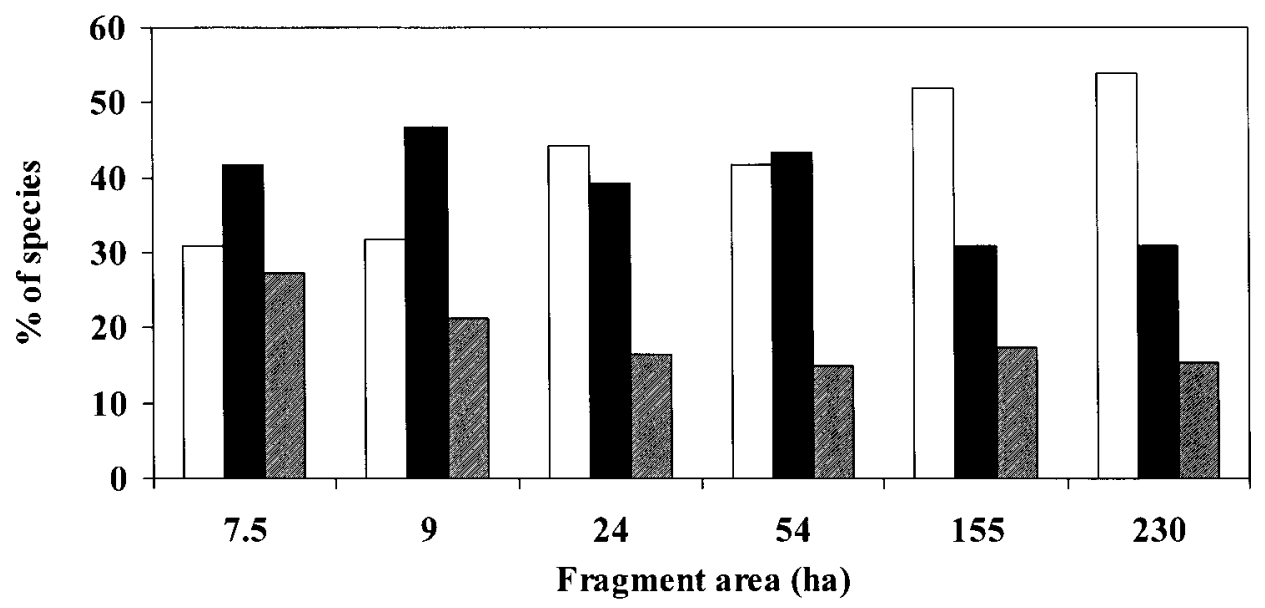

Figure 3. Percentage of forest-dependent (white bars), semi-dependent (solid bars) and independent (grey bars) species (from Silva 1995) recorded in each of six forest fragments at the Triângulo Mineiro region. Based on total sampling effort as in Table 1.

Antwren, Helmeted Manakin), the occurrence of the other five forest-dependent endemics was related to the presence of patches of flooded forest in the fragment (Tables 1 and 2).

Larger forest fragments had significantly more species exclusive to them (i.e. species exclusive to one fragment) than smaller fragments (Table 2), both for all species and for forest-dependent species, independent of sampling effort. 
Table 2. Number of species in selected species categories for six forest fragments in the Triângulo Mineiro region, Minas Gerais. Pearson's correlation coefficients $(r)$ between species category and fragment area for total and controlled sampling efforts are given

\begin{tabular}{|c|c|c|c|c|c|c|c|c|c|}
\hline \multirow[t]{2}{*}{ Species category } & \multirow[t]{2}{*}{ Sampling effort ${ }^{a}$} & \multicolumn{6}{|c|}{ Fragment area (ha) } & \multirow[t]{2}{*}{$r$} & \multirow[t]{2}{*}{$P$} \\
\hline & & $7 \cdot 5$ & 9 & 24 & 54 & 155 & 230 & & \\
\hline \multicolumn{10}{|l|}{ Exclusive species } \\
\hline Total & & 3 & 2 & 2 & 7 & 7 & 21 & 0.874 & 0.023 \\
\hline Controlled & & 3 & 4 & 2 & 7 & 11 & 15 & 0.855 & 0.030 \\
\hline \multicolumn{10}{|c|}{ Exclusive forest-dependent species } \\
\hline Total & & o & 1 & o & 1 & 5 & 15 & 0.860 & 0.028 \\
\hline Controlled & & $\mathrm{o}$ & 1 & o & 2 & 9 & 9 & 0.871 & 0.024 \\
\hline \multicolumn{10}{|c|}{ Forest-dependent cerrado endemics } \\
\hline Total & & 6 & 2 & 5 & 7 & 2 & 7 & 0.109 & 0.837 \\
\hline Controlled & & 6 & 2 & 5 & 7 & 2 & 4 & -0.138 & 0.794 \\
\hline
\end{tabular}

${ }^{a}$ Total, total sampling effort as in Table 1; controlled, same sampling effort for all forest fragments (first 24 observation hours and first 320 mist-netting hours).

Most bird species in fragments were insectivores $(\sim 50 \%$ of the species $)$ and omnivores ( $30 \%$ of the species), with small proportions of frugivores, granivores and nectarivores. The proportion of species in each foraging guild changed little with fragment size, except for that of granivorous species, which decreased significantly $(r=-0.937, d f=5, P=0.006)$ as fragment size increased. Proportions of all other foraging guilds varied randomly with fragment size (Table 3, data from Appendix 1).

\section{Discussion}

The number of species and genera was much greater in larger forest fragments than in smaller ones, as would be expected from a number of previous studies (reviews in Abbott 1980, Andrén 1994, Turner 1996). Smaller fragments had fewer forest dependent species than forest independent species, a pattern found also by Christiansen and Pitter (1997), while Aleixo and Vielliard (1995) found that $62 \%$ of bird species recorded in a 251 ha forest fragment were forest dependent, a value close to but higher than that at the 230 ha forest of this study.

Since the ratio of forest interior to forest border decreases with an increase in

Table 3. Number (\%) of species recorded at six forest fragments in the Triângulo Mineiro region, Minas Gerais, Brazil, for each of five dietary groups. Pearson's correlation coefficients ( $r$ ) and probability values for the correlations between fragment area and diet (percentage of species of diet guild) are also shown

\begin{tabular}{|c|c|c|c|c|c|c|c|c|}
\hline \multirow[t]{2}{*}{ Diet guild } & \multicolumn{6}{|c|}{ Fragment area (ha) } & \multirow[t]{2}{*}{$r$} & \multirow[t]{2}{*}{$P$} \\
\hline & $7 \cdot 5$ & 9 & 24 & 54 & 155 & 230 & & \\
\hline Insectivore & $26(47 \cdot 3)$ & $19(40.4)$ & $31(50.0)$ & $34(50.0)$ & $39(48.2)$ & $53(51.5)$ & 0.650 & 0.163 \\
\hline Omnivore & $15(27.3)$ & $15(31.9)$ & $19(30.7)$ & $20(29.4)$ & 25 (30.9) & $30(29.1)$ & 0.071 & 0.894 \\
\hline Frugivore & $5(9.1)$ & $6(12.8)$ & $2(3.2)$ & $4(5.9)$ & $7(8.6)$ & $10(9.7)$ & -0.091 & 0.864 \\
\hline Granivore & $6(10.9)$ & 5 (10.6) & $6(9.7)$ & $6(8.8)$ & $5(6.2)$ & $4(3.9)$ & -0.937 & 0.006 \\
\hline Nectarivore & $3(5 \cdot 5)$ & $2(4 \cdot 3)$ & $4(6.5)$ & $4(5.9)$ & $5(6.2)$ & $5(4.9)$ & 0.231 & 0.660 \\
\hline
\end{tabular}


fragment area, smaller fragments are expected to have fewer forest-dependent species and more forest-independent species, such as granivores. In this study, only the proportion of granivores in the total bird community varied with fragment size. Leck (1979) suggested that fringillids (which are granivores) are abundant and probably increasing near the forest fragment he studied at Ecuador. In temperate forests of Chile, mutualists (pollinators and fruit-dispersers) were less affected by fragmentation than non-forest mutualists (Willson et al. 1994). Also, Stouffer and Bierregaard (1995a) did not detect negative fragmentation effects on hummingbirds in the Amazon. The number of species and the number of individuals of understorey insectivores in Amazonian forest fragments decreased after isolation (Stouffer and Bierregaard 1995b).

Nest predation has been claimed to be a major cause of species loss in forest fragments (Ambuel and Temple 1983, Wilcove et al. 1986, Robinson et al. 1995). It is important to stress, however, that Melo and Marini (1997) found no relationship between forest size and artificial nest predation rates in 10 fragments (including the five largest) of the region studied here. Leite and Marini (1999) also found no relationship between artificial nest predation and forest area for 19 similar-sized forest fragments in a region $500 \mathrm{~km}$ distant. These two studies suggest that, at least at the current level of forest fragmentation in these regions, nest predation does not seem to be affecting the loss of species.

Birds that occur outside the cerrado biome as well as within it may become locally extinct in the cerrado without becoming globally extinct. Endemic species, however, become globally extinct when extirpated from their restricted range (Pimm and Askins 1995). Of the seven forest-dependent endemic or quasiendemic cerrado species, only the Bare-faced Curassow seems to be at a significant threat of global extinction in the wild, probably because it is a large (2.7-2.8 $\mathrm{kg}$, Sick 1997) frugivore that is hunted for meat. Some of the six other species, despite their apparent safety from global extinction through forest destruction, may be affected by the lack of appropriate habitat (flooded gallery forests, which is not abundant). Thus, even though these species do not seem to be area sensitive, they may suffer from the destruction of their specific habitat. Two cerrado endemics (Large-billed Antwren, Helmeted Manakin) were locally abundant in all forest fragments, and are probably safe from any immediate risk of global extinction.

Paradoxically, 9 of the 12 species endemic or quasi-endemic to the cerrado region, were recorded in the small fragments (Appendix 1), implying that they are not area sensitive and that they may have the capacity to disperse among the fragments. This finding is contrary to what was expected and in agreement with other studies, such as paramo endemic birds of northern Andes (Vuilleumier 1970), chaparral endemic birds of North America (Soulé et al. 1988), and temperate rainforest endemic birds in Chile (Willson et al. 1994). It is also important to note that all large species that are hunted for meat (tinamous and curassows) were absent from the two smaller fragments.

Most forest-dependent cerrado endemics seem to respond negatively to the lack of flooded forests. Forest fragments without flooded forest microhabitats (9 and $155 \mathrm{ha}$ ) held fewer species or relatively small populations of forest dependent species endemic to the cerrado region than the other four fragments. The presence of six of the seven forest-dependent species endemic to the cerrado 
region in the smaller ( 7.5 ha) fragment may be due to the fact that it is an entirely flooded forest. The importance of humid forest zones for conservation has already been stressed by Christiansen and Pitter (1997).

In conclusion, the forest-dependent species endemic to the cerrado region do not seem to be area sensitive but seem to be partially dependent on the flooded forests of the region. Considering that the cerrado biome has been rapidly disappearing (Dias 1990, Klink et al. 1993, Willis and Oniki 1993), conservation efforts in the region should preserve urgently both large and small fragments and especially flooded forests. The conservation of area-sensitive species, of large-bodied species, and of hunted species of the region can be achieved by preserving large forest fragments, whereas the conservation of small endemic passerines can be achieved by preserving flooded forests in both large and small forest fragments.

\section{Acknowledgements}

I was supported by a post-doctorate fellowship from CNPq. I am in debt to the property owners of the Triângulo Mineiro region and the administrators of "Fazenda Experimental do Glória" and "Reserva Ecológica do Panga" who allowed me to work on lands they own or manage. C. Melo, G. M. Oliveira, M. F. Pereira, and T. A. Melo-Júnior helped with fieldwork. Professor A. Ruszczyk-Neto, and I. Schiavini provided partial logistical support. F. A. S. Fernandez, R. O. Bierregaard, Jr., and anonymous reviewers improved the manuscript with their criticisms. 
Appendix 1. List of species observed or captured in the six forest fragments at the Triângulo Mineiro region, Minas Gerais state.

Aquatic (Threskiornithidae, Ardeidae, Alcedinidae), aerial (Falconiformes) and nocturnal (Tytonidae, Strigidae and Caprimulgidae) species are excluded. Species sequence and taxonomy follow Sibley and Monroe (1990).

\begin{tabular}{|c|c|c|c|c|c|c|c|c|}
\hline \multirow[t]{2}{*}{ Species } & \multicolumn{6}{|c|}{ Fragment area (ha) } & \multirow[t]{2}{*}{$\operatorname{Diet}^{a}$} & \multirow{2}{*}{$\begin{array}{l}\text { Forest }^{b} \\
\text { dependence }\end{array}$} \\
\hline & 230 & 155 & 54 & 24 & 9 & $7 \cdot 5$ & & \\
\hline Tinamus solitarius & $x$ & - & - & $X$ & - & - & ONI & A \\
\hline Crypturellus obsoletus & - & $x$ & - & - & - & - & ONI & A \\
\hline Crypturellus parvirostris & $x$ & - & - & $X$ & - & - & ONI & $\mathrm{C}$ \\
\hline Penelope superciliaris & - & $x$ & $X$ & $X$ & - & - & ONI & A \\
\hline Crax fasciolata & $x$ & - & $X$ & - & - & - & ONI & A \\
\hline Odontophorus capueira & $x$ & - & - & - & - & - & ONI & A \\
\hline Picumnus minutissimus & $x$ & $x$ & $X$ & $X$ & $x$ & $x$ & INS & B \\
\hline Veniliornis passerinus & $x$ & - & - & - & - & - & INS & $\mathrm{B}$ \\
\hline Colaptes melanochloros & - & - & $X$ & $X$ & - & - & INS & $\mathrm{B}$ \\
\hline Colaptes campestris & - & - & - & - & $x$ & $x$ & INS & $\mathrm{C}$ \\
\hline Campephilus melanoleucos & $x$ & $x$ & $X$ & $X$ & - & - & INS & A \\
\hline Dryocopus lineatus & $x$ & - & - & $X$ & $x$ & $x$ & INS & $\mathrm{B}$ \\
\hline Ramphastos toco & $x$ & $x$ & $X$ & - & $x$ & $x$ & FRU & $\mathrm{B}$ \\
\hline Galbula ruficauda & $x$ & - & $X$ & $X$ & - & $x$ & INS & $\mathrm{B}$ \\
\hline Nonnula rubecula & $x$ & $X$ & - & - & - & - & INS & A \\
\hline Monasa nigrifrons & $x$ & $x$ & - & - & - & - & INS & A \\
\hline Trogon surrucura & $x$ & $x$ & - & - & - & - & ONI & A \\
\hline Momotus momota & $x$ & - & - & - & - & - & INS & A \\
\hline Baryphthengus ruficapillus & - & $x$ & - & $X$ & - & - & INS & A \\
\hline Piaya cayana & $x$ & $x$ & $X$ & $X$ & $x$ & $x$ & INS & $\mathrm{B}$ \\
\hline Tapera naevia & $x$ & - & - & - & - & - & INS & $\mathrm{C}$ \\
\hline Crotophaga ani & $x$ & - & $X$ & - & - & $x$ & ONI & $\mathrm{C}$ \\
\hline Guira guira & - & $x$ & - & $X$ & $x$ & $x$ & ONI & $\mathrm{C}$ \\
\hline Phaethornis pretrei & $x$ & $x$ & $X$ & $X$ & $x$ & $x$ & NEC & $\mathrm{B}$ \\
\hline Lophornis magnificus & - & $x$ & - & - & - & - & NEC & $\mathrm{B}$ \\
\hline Thalurania furcata & $x$ & $x$ & $X$ & $?$ & $x$ & $x$ & NEC & $\mathrm{B}$ \\
\hline Amazilia versicolor & $x$ & $X$ & - & $?$ & - & $x$ & NEC & A \\
\hline Amazilia lactea & - & $x$ & - & - & - & - & NEC & A \\
\hline Colibri serrirostris & - & - & $X$ & - & - & - & NEC & $\mathrm{B}$ \\
\hline Melanotrochilus fuscus & $x$ & - & - & - & - & - & NEC & A \\
\hline Anthracothorax nigricollis & $x$ & - & $?$ & - & - & - & NEC & $\mathrm{B}$ \\
\hline Eupetomena macroura & - & - & - & $X$ & - & - & NEC & $\mathrm{C}$ \\
\hline Columba cayennensis & $x$ & $x$ & $X$ & $X$ & - & - & GRA & A \\
\hline Columba picazuro & - & - & - & $X$ & $x$ & - & GRA & $\mathrm{B}$ \\
\hline Columbina talpacoti & $x$ & $x$ & $X$ & $X$ & $x$ & $x$ & GRA & $\mathrm{C}$ \\
\hline Scardafella squammata & - & - & - & $X$ & $x$ & $x$ & GRA & $\mathrm{C}$ \\
\hline Leptotila verreauxi & $x$ & $x$ & $X$ & - & $x$ & $x$ & FRU & B \\
\hline Leptotila rufaxilla & $x$ & - & - & - & - & - & FRU & $\mathrm{A}$ \\
\hline Amazona aestiva & $x$ & - & - & - & $x$ & $x$ & FRU & $\mathrm{A}$ \\
\hline Amazona amazonica & $x$ & - & - & - & - & - & FRU & A \\
\hline Aratinga aurea & $x$ & $?$ & - & - & $x$ & $x$ & FRU & $\mathrm{C}$ \\
\hline Aratinga auricapilla & $x$ & - & - & - & - & - & FRU & A \\
\hline Brotogeris chiriri & $x$ & $x$ & $X$ & - & - & - & FRU & B \\
\hline Cyanocorax cristatellus & - & - & - & $X$ & $x$ & - & INS & $\mathrm{C}$ \\
\hline Todirostrum cinereum & - & - & $X$ & - & $x$ & $x$ & INS & $\mathrm{B}$ \\
\hline Corythopis delalandi & - & $x$ & - & - & - & - & INS & A \\
\hline Camptostoma obsoletum & $x$ & $x$ & - & - & - & - & INS & $\mathrm{C}$ \\
\hline Phaeomyias murina & $x$ & $X$ & - & - & - & - & INS & $\mathrm{C}$ \\
\hline Leptopogon amaurocephalus & $x$ & $X$ & $X$ & $X$ & - & $x$ & INS & A \\
\hline
\end{tabular}


Appendix 1. continued

\begin{tabular}{|c|c|c|c|c|c|c|c|c|}
\hline \multirow[t]{2}{*}{ Species } & \multicolumn{6}{|c|}{ Fragment area (ha) } & \multirow[t]{2}{*}{$\operatorname{Diet}^{a}$} & \multirow{2}{*}{$\begin{array}{l}\text { Forest }^{b} \\
\text { dependence }\end{array}$} \\
\hline & 230 & 155 & 54 & 24 & 9 & $7 \cdot 5$ & & \\
\hline Elaenia mesoleuca & - & $X$ & - & - & - & - & ONI & $\mathrm{A}$ \\
\hline Elaenia flavogaster & $X$ & - & - & $X$ & - & $?$ & ONI & $\mathrm{B}$ \\
\hline Elaenia cristata & $x$ & - & - & - & - & - & ONI & $\mathrm{C}$ \\
\hline Elaenia obscura & $x$ & $X$ & - & - & - & - & ONI & A \\
\hline Tolmomyias sulphurescens & $X$ & $X$ & $x$ & $X$ & $x$ & $X$ & INS & A \\
\hline Phyllomyias fasciatus & - & $X$ & - & - & - & - & INS & $\mathrm{B}$ \\
\hline Platyrinchus mystaceus & $X$ & - & - & $x$ & - & - & INS & $\mathrm{A}$ \\
\hline Cnemotriccus fuscatus & $X$ & $X$ & $X$ & $X$ & $x$ & - & INS & $\mathrm{A}$ \\
\hline Lathrotriccus euleri & $X$ & $X$ & $X$ & $X$ & - & $X$ & INS & $\mathrm{A}$ \\
\hline Pyrocephalus rubinus & - & - & - & - & - & $x$ & INS & $\mathrm{C}$ \\
\hline Contopus cinereus & $x$ & - & - & - & - & - & INS & $\mathrm{A}$ \\
\hline Colonia colonus & $x$ & - & - & - & - & - & INS & A \\
\hline Casiornis rufa & $X$ & - & - & $X$ & - & - & INS & A \\
\hline Sirystes sibilator & $x$ & - & - & - & - & - & INS & $\mathrm{A}$ \\
\hline Myiarchus ferox & $X$ & - & $X$ & $X$ & $X$ & $?$ & INS & $\mathrm{B}$ \\
\hline Myiarchus tyrannulus & $x$ & $X$ & - & - & - & - & INS & $\mathrm{B}$ \\
\hline Tyrannus melancholicus & $x$ & $X$ & $x$ & $x$ & $X$ & $X$ & INS & $\mathrm{C}$ \\
\hline Tyrannus albogularis & $x$ & - & - & - & - & - & INS & $\mathrm{C}$ \\
\hline Tyrannus savanna & - & $X$ & - & - & - & $X$ & INS & $\mathrm{C}$ \\
\hline Suiriri suiriri & - & - & - & - & - & $X$ & INS & $\mathrm{C}$ \\
\hline Serpophaga subcristata & - & - & - & - & - & $X$ & INS & $\mathrm{B}$ \\
\hline Hemitriccus margaritaceiventer & - & - & $X$ & - & - & - & INS & $\mathrm{B}$ \\
\hline Megarhynchus pitangua & $x$ & $X$ & $X$ & $X$ & $X$ & $X$ & ONI & $\mathrm{B}$ \\
\hline Myiozetetes cayanensis & $X$ & $X$ & - & - & - & $X$ & ONI & $\mathrm{A}$ \\
\hline Myiozetetes similis & - & $X$ & $X$ & - & - & - & INS & $\mathrm{B}$ \\
\hline Conopias trivirgata & $x$ & - & - & - & - & - & INS & $\mathrm{B}$ \\
\hline Myiodynastes maculatus & - & $X$ & $X$ & - & - & - & ONI & $\mathrm{A}$ \\
\hline Legatus leucophaius & $x$ & $X$ & - & $X$ & $X$ & - & ONI & $\mathrm{B}$ \\
\hline Pitangus sulphuratus & $x$ & $X$ & $X$ & $x$ & $X$ & $x$ & ONI & $\mathrm{C}$ \\
\hline Pachyramphus castaneus & $x$ & $X$ & - & - & - & - & INS & $\mathrm{A}$ \\
\hline Pachyramphus polycopterus & - & - & - & $X$ & - & - & INS & $\mathrm{B}$ \\
\hline Tityra cayana & $x$ & $X$ & - & - & - & - & ONI & A \\
\hline Antilophia galeata & $x$ & $x$ & $X$ & $x$ & $X$ & $X$ & FRU & $\mathrm{A}$ \\
\hline Neopelma palescens & - & $X$ & - & $X$ & - & - & FRU & A \\
\hline Pipra fasciicauda & $x$ & - & - & - & - & - & FRU & A \\
\hline Taraba major & $x$ & $X$ & - & - & - & - & INS & $\mathrm{B}$ \\
\hline Thamnophilus doliatus & - & - & $X$ & $X$ & - & $X$ & INS & $\mathrm{B}$ \\
\hline Thamnophilus punctatus & $x$ & $X$ & $x$ & - & - & - & INS & A \\
\hline Thamnophilus caerulescens & $x$ & $X$ & $X$ & $X$ & $X$ & - & INS & $\mathrm{A}$ \\
\hline Dysithamnus mentalis & $x$ & $X$ & - & - & - & - & INS & $\mathrm{A}$ \\
\hline Drymophila sp. & $x$ & - & - & - & - & - & INS & $\mathrm{A}$ \\
\hline Herpsilochmus longirostris & $x$ & $x$ & $x$ & $x$ & $x$ & $X$ & INS & $\mathrm{A}$ \\
\hline Herpsilochmus pileatus & $x$ & $X$ & - & - & - & - & INS & $\mathrm{B}$ \\
\hline Synallaxis frontalis & $x$ & - & $x$ & $?$ & - & - & INS & A \\
\hline Synallaxis candei & $x$ & $X$ & $X$ & - & - & - & INS & $\mathrm{B}$ \\
\hline Cranioleuca vulpina & - & - & $X$ & - & - & - & INS & $\mathrm{B}$ \\
\hline Lochmias nematura & $x$ & - & $X$ & $X$ & - & $x$ & INS & A \\
\hline Philydor dimidiatus & $?$ & - & $X$ & - & - & $X$ & INS & A \\
\hline Philydor lichtensteini & - & - & $X$ & - & - & - & INS & A \\
\hline Phacellodomus rufifrons & - & - & - & - & $x$ & - & INS & $\mathrm{B}$ \\
\hline Automolus rectirostris & $x$ & - & $X$ & $X$ & - & $x$ & INS & $\mathrm{A}$ \\
\hline Xenops rutilans & $X$ & $X$ & $x$ & - & - & - & INS & A \\
\hline Sittasomus griseicapillus & $X$ & $x$ & $x$ & - & - & - & INS & $\mathrm{A}$ \\
\hline
\end{tabular}


Appendix 1. continued

\begin{tabular}{|c|c|c|c|c|c|c|c|c|}
\hline \multirow[t]{2}{*}{ Species } & \multicolumn{6}{|c|}{ Fragment area (ha) } & \multirow[t]{2}{*}{$\operatorname{Diet}^{a}$} & \multirow{2}{*}{$\begin{array}{l}\text { Forest }^{b} \\
\text { dependence }\end{array}$} \\
\hline & 230 & 155 & 54 & 24 & 9 & $7 \cdot 5$ & & \\
\hline Lepidocolaptes angustirostris & $x$ & $x$ & - & $x$ & - & - & INS & $\mathrm{C}$ \\
\hline Conopophaga lineata & $x$ & $x$ & - & $X$ & - & - & INS & A \\
\hline Cyclarhis gujanensis & $x$ & $X$ & $X$ & $X$ & $X$ & $X$ & INS & $\mathrm{B}$ \\
\hline Vireo olivaceus & - & $x$ & $X$ & - & - & - & INS & A \\
\hline Turdus leucomelas & $x$ & $x$ & $X$ & $X$ & $x$ & $X$ & ONI & $\mathrm{B}$ \\
\hline Turdus amaurochalinus & $x$ & $x$ & $X$ & $x$ & $X$ & - & ONI & $\mathrm{B}$ \\
\hline Turdus rufiventris & - & - & $X$ & - & - & - & ONI & C \\
\hline Turdus nigriceps & - & - & - & - & $X$ & - & ONI & A \\
\hline Thryothorus leucotis & $x$ & $x$ & $x$ & $x$ & $x$ & $x$ & INS & A \\
\hline Troglodytes aedon & $x$ & $x$ & - & - & - & - & INS & $\mathrm{C}$ \\
\hline Polioptila dumicola & $x$ & - & $X$ & $X$ & $X$ & $X$ & INS & $\mathrm{B}$ \\
\hline Arremon flavirostris & $x$ & - & $x$ & $x$ & - & - & ONI & $\mathrm{A}$ \\
\hline Parula pitiayumi & - & $X$ & - & - & - & - & INS & A \\
\hline Basileuterus hypoleucus & $x$ & $x$ & $x$ & $x$ & $x$ & $x$ & INS & $\mathrm{A}$ \\
\hline Basileuterus flaveolus & $x$ & $X$ & $X$ & $X$ & $X$ & - & INS & A \\
\hline Basileuterus leucophrys & $x$ & - & $X$ & $x$ & - & $x$ & INS & A \\
\hline Coereba flaveola & - & $x$ & $X$ & - & $x$ & $x$ & ONI & $\mathrm{B}$ \\
\hline Conirostrum speciosum & $x$ & - & - & - & - & - & INS & A \\
\hline Cissopis leveriana & $x$ & - & - & - & - & - & FRU & A \\
\hline Hemithraupis guira & $x$ & $x$ & - & - & - & - & INS & $\mathrm{A}$ \\
\hline Nemosia pileata & $x$ & $x$ & - & - & $x$ & $x$ & INS & A \\
\hline Eucometis penicillata & $x$ & $X$ & $X$ & $x$ & $X$ & $x$ & ONI & A \\
\hline Thraupis palmarum & $x$ & $x$ & $X$ & $x$ & - & - & ONI & $\mathrm{B}$ \\
\hline Thraupis sayaca & $x$ & $X$ & $X$ & $X$ & - & $x$ & ONI & $\mathrm{B}$ \\
\hline Ramphocelus carbo & - & - & $X$ & $X$ & - & - & ONI & $\mathrm{B}$ \\
\hline Tachyphonus rufus & $x$ & - & - & - & - & - & ONI & A \\
\hline Trichothraupis melanops & $x$ & - & - & - & - & - & ONI & A \\
\hline Euphonia chlorotica & $x$ & $x$ & $X$ & $x$ & $X$ & $X$ & ONI & $\mathrm{B}$ \\
\hline Euphonia cyanocephala $(=$ musica $)$ & - & $x$ & - & - & $X$ & - & FRU & $\mathrm{A}$ \\
\hline Tangara cayana & $x$ & $x$ & $X$ & $x$ & $X$ & $X$ & ONI & $\mathrm{C}$ \\
\hline Dacnis cayana & $x$ & $x$ & $X$ & - & $x$ & $x$ & ONI & B \\
\hline Tersina viridis & $x$ & $x$ & - & $X$ & $X$ & - & ONI & A \\
\hline Molothrus bonariensis & - & - & $x$ & - & - & - & GRA & $\mathrm{C}$ \\
\hline Coryphospingus cucullatus & $x$ & $X$ & - & $X$ & $X$ & $x$ & GRA & $\mathrm{B}$ \\
\hline Volatinia jacarina & - & $x$ & $X$ & $X$ & - & $x$ & GRA & $\mathrm{C}$ \\
\hline Sporophila nigricollis & $x$ & - & $X$ & - & - & $X$ & GRA & $\mathrm{C}$ \\
\hline Sporophila caerulescens & - & $X$ & - & - & $?$ & $x$ & GRA & $\mathrm{C}$ \\
\hline Sporophila lineola & - & - & $X$ & - & - & - & GRA & $\mathrm{C}$ \\
\hline Saltator similis & $x$ & $x$ & $X$ & $x$ & $x$ & $x$ & ONI & $\mathrm{B}$ \\
\hline Saltator maximus & $x$ & $x$ & $X$ & - & $X$ & $x$ & ONI & $\mathrm{A}$ \\
\hline Cacicus haemorhous & $x$ & - & - & - & - & - & ONI & B \\
\hline Icterus cayanensis & $x$ & - & - & - & - & - & ONI & B \\
\hline Icteridae sp. & $x$ & $x$ & - & - & - & - & ONI & $\mathrm{C}$ \\
\hline Number of genera & 89 & 70 & 57 & 56 & 42 & 51 & 115 & \\
\hline Number of species & 104 & 81 & 68 & 62 & 47 & 55 & 145 & \\
\hline
\end{tabular}

${ }^{a}$ Diet: INS, insectivore; ONI, omnivore; FRU, frugivore; GRA, granivore; NEC, nectarivore. Following Willis (1979), Motta-Júnior (1990), Sick (1997) and personal observations.

${ }^{b}$ Habitat: A, forest dependent species; B, forest semi-dependent species; C, forest-independent species. Following Silva (1995) classification. 


\section{References}

Abbott, I. (1980) Theories dealing with the ecology of landbirds on islands. Adv. Ecol. Res. 11: 329-371.

Aleixo, A. and Vielliard, J. M. E. (1995) Composição e dinâmica da avifauna da mata de Santa Genebra, Campinas, São Paulo, Brasil. Rev. Brasil. Zool. 12: 493-511.

Ambuel, B. and Temple, S. A. (1983) Area dependent changes in the bird communities and vegetation of southern Wisconsin forest. Ecology 64: 1057-1068.

Andrén, H. (1994) Effects of habitat fragmentation on birds and mammals in landscapes with different proportions of suitable habitat: a review. Oikos 71: 355-366.

Anjos, L. and Boçon, R. (1999) Bird communities in natural forest patches in Southeastern Brazil. Wilson Bull. 111: 397-414.

Araújo, G. M. and Haridasan, M. (1997) Estrutura fitossociológica de duas matas mesófilas semidecíduas, em Uberlândia, Triângulo Mineiro. Naturalia, São Paulo 22: 115-129.

Araújo, G. M., Rodrigues, L. A. and Ivizi, L. (1997) Estrutura fitossociológica e fenologia de espécies lenhosas de mata decídua em Uberlândia, MG. Pp. 22-28 in L. L. Leite and C. H. Sato, eds. Contribuição ao conhecimento ecológico do cerrado. Brasília: Universidade de Brasília.

Bierregaard, R. O., Jr. and Lovejoy, T. E. (1986) Birds of Amazonian forest fragments: effects of insularization. Proc. XIX Internatn. Orn. Congr. 19: 1564-1579.

Bierregaard, R. O., Jr. and Lovejoy, T. E. (1989) Effects of forest fragmentation on Amazonian understory bird communities. Acta Amaz. 19: 215-241.

Bierregaard, R. O., Jr., Lovejoy, T. E., Kapos, V., Santos, A. A. and Hutchings, R. W. (1992) The biological dynamics of tropical forest fragments. Bioscience 42: 859-866.

Christiansen, M. B. and Pitter, E. (1997) Species loss in a forest bird community near Lagoa Santa in southeastern Brazil. Biol. Conserv. 80: 23-32.

Dias, B. F. S. (1990) Conservação da natureza no cerrado brasileiro. Pp. 583-640 in M. N. Pinto, ed. Cerrado: caracterização, ocupação e perspectivas. Brasília: Editora Universidade de Brasília.

Hagan, J. M., Matthew van der Haegen, W. and McKinley, P. S. (1996) The early development of forest fragmentation effects on birds. Conserv. Biol. 10: 188-202.

Kattan, G. H. and Alvarez-López, H. (1996) Preservation and management of biodiversity in fragmented landscapes in the Colombian Andes. Pp. 3-18 in J. Schelhas and R. Greenberg, eds. Forest patches in tropical landscapes. Washington, D.C: Island Press.

Klink, C. A., Moreira, A. G. and Solbrig, O. T. (1993) Ecological impact of agricultural development in the Brazilian cerrados. Pp. 259-282 in M. D. Young and O. T. Solbrig, eds. The world's savannas. Economic driving forces, ecological constraints and policy options for sustainable land use, 12. Paris: UNESCO; New York: Parthenon Publishers (Man and Biosphere Series).

Leck, C. F. (1979) Avian extinctions in an isolated tropical wet-forest preserve, Ecuador. Auk 96: 343-352.

Leite, L. O. and Marini, M. Â. (1999) The effects of forest fragmentation on predation rates of artificial bird nests in Minas Gerais. Ciência Cult. 51: 34-37.

Melo, C. and Marini, M. Â. (1997) Predação de ninhos artificiais em fragmentos de matas do Brasil central. Orn. Neotrop. 8: 7-14.

Motta-Júnior, J. C. (1990) Estrutura trófica e composição das avifaunas de três hábitats terrestres na região central do estado de São Paulo. Ararajuba 1: 65-71.

Ott, L. (1988) An introduction to statistical methods and data analysis. Boston: PWS-Kent.

Pimm, S. L. and Askins, R. A. (1995) Forest losses predict bird extinction in eastern North America. Proc. Natl. Acad. Sci. USA 92: 9343-9347.

Robinson, S. K., Thompson, F. R., III, Donovan, T. M., Whitehead, D. R. and Faaborg, J. (1995) Regional forest fragmentation and the nesting success of migratory birds. Science 267: 1987-1990. 
Rodrigues, L. A. and Araújo, G. M. (1997) Levantamento florístico de uma mata decídua em Uberlândia, Minas Gerais, Brasil. Acta Bot. Brasíl. 11: 229-236.

Rosa, R., Lima, S. C. and Assunção, W. L. (1991) Abordagem prelimilar das condições climáticas de Uberlândia (MG). Soc. e Nat., Uberlândia 3: 91-108.

Schiavini, I. and Araújo, G. M. (1989) Considerações sobre a vegetação da Reserva Ecológica do Panga (Uberlândia). Soc. e Nat., Uberlândia 1: 61-66.

Shafer, C. L. (1990) Nature reserves. Island theory and conservation practice. Washington, D.C.: Smithsonian Institution Press.

Sibley, C. G. and Monroe, B. L., Jr. (1990) Distribution and taxonomy of birds of the World. New Haven: Yale University Press.

Sick, H. (1997) Ornitologia Brasileira. Rio de Janeiro: Editora Nova Fronteira.

Silva, J. M. C. (1995) Birds of the Cerrado region, South America. Steenstrupia 21: 69-92.

Soulé, M. E., Bolger, D. T., Alberts, A. C., Wright, J., Sorice, M. and Hill, S. (1988) Reconstructed dynamics of rapid extinctions of chaparral-requiring birds in urban habitat islands. Conserv. Biol. 2: 75-92.

Stouffer, P. C. and Bierregaard, R. O., Jr. (1995a) Effects of forest fragmentation on understory hummingbirds in Amazonian Brazil. Conserv. Biol. 9: 1085-1094.

Stouffer, P. C. and Bierregaard, R. O., Jr. (1995b) Use of Amazonian forest fragments by understory insectivorous birds. Ecology 76: 2429-2445.

Turner, I. M. (1996) Species loss in fragments of tropical rain forest: a review of the evidence. J. Appl. Ecol. 33: 200-209.

Vuilleumier, F. (1970) Insular biogeography in continental regions. I. The northern Andes of South America. Am. Nat. 104: 373-388.

Wilcove, D. S., McLellan, C. H. and Dobson, A. P. (1986) Habitat fragmentation in the temperate zone. Pp. 237-256 in M. E. Soulé, ed. Conservation biology. The science of scarcity and diversity. Sunderland, MA: Sinauer.

Willis, E. O. (1979) The composition of avian communities in remanescent woodlots in southern Brazil. Pap. Avulsos Zool., São Paulo 33: 1-25.

Willis, E. O. and Oniki, Y. (1993) New and reconfirmed birds from the state of São Paulo, Brazil, with notes on disappearing species. Bull. Brit. Orn. Club 113: 23-34.

Willson, M. F., Santo, T. L., Sabag, C., and Armesto, J. J. (1994) Avian communities of fragmented south-temperate rainforests in Chile. Conserv. Biol. 8: 508-520.

MIGUEL Â MARINI

Departamento de Biociências, Universidade Federal de Uberlândia, Uberlândia, MG 38405-382 Brazil.

Present address: Departamento de Biologia Geral, C.P. 486, ICB, Universidade Federal de Minas Gerais, Belo Horizonte, MG 30161-970 Brazil. E-mail: marini@mono.icb.ufmg.br. 
